\title{
HALIOTIS TUBERCULATA。
}

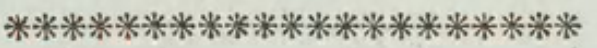 \\ CHARACTER GENERICUS.
}

Animal Limax.

Testa auriformis, pateus; spira occultata laterali; disco longitudinaliter poris pertuso.

$$
\text { Lin. Syst. Nat. p. } 1255 .
$$

CHARACTER SPECIFICUS, EंC.

HALIOTIS TUBERCULATA. H. testa subovata, dorso transversim rugoso, tuberculato.

$$
\text { Lin. Syst. Nat. p. } 1256 .
$$

Auris marina.

$$
\text { Rondel. pisc. } 5 .
$$

Patella major, seu fera.

Gesn. Aquat. 807, 808.

In oris plurimis Europæis adhæret rupibus Haliotis vulgaris seu tuberculata eodem modo quo solet Patellarum genus. Color testæ generalis exterior infuscatur, interdum ferrugineo seu virescente undulatus; interior est quasi margaritaceus, pro variata luce iricolor. 



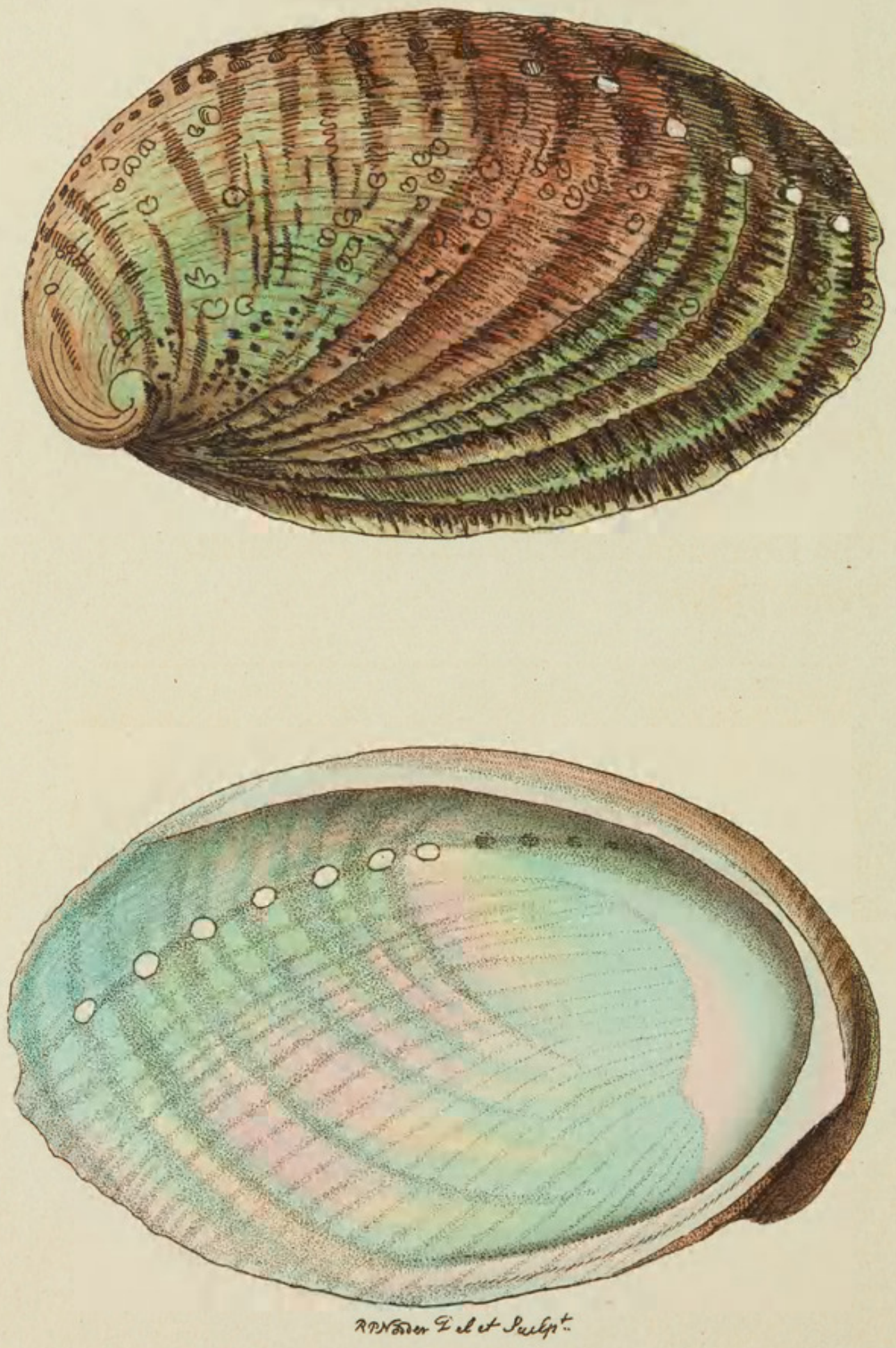
THE

\section{TUBERCULATED HALIOTIS,}

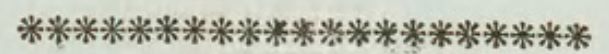

GENERIC CHARACTER.

Animal allied to a Slug.

Shell ear-shaped, spreading, with obliterated lateral spire; the disc longitudinally perforated with pores.

SPECIFIC CHARACTER, छc.

HALIOTIS with subovate, transversly wrinkled, tuberculated shell.

The Common HALIOTIS or Ear-shell.

Venus's Ear.

The common or tuberculated Haliotis is found on many of the European coasts, adhering, in the manner of the genus Patella, to rocks. The usual colour of the shell on the outside is brown, sometimes varied either with ferruginous or greenish clouds: of the inside bright pearl-colour with iridescent variegarions. 


\section{$2 \mathrm{BHL}$ Biodiversity Heritage Library}

Shaw, George. 1805. "The Tuberculated Haliotis, Haliotis tuberculata [PI. 715]." The Naturalist's Miscellany 17(CXCIII), https://doi.org/10.5962/p.311152.

View This Item Online: https://www.biodiversitylibrary.org/item/281954

DOI: https://doi.org/10.5962/p.311152

Permalink: https://www.biodiversitylibrary.org/partpdf/311152

\section{Holding Institution}

Museums Victoria

\section{Sponsored by}

Atlas of Living Australia

\section{Copyright \& Reuse}

Copyright Status: Public domain. The BHL considers that this work is no longer under copyright protection.

This document was created from content at the Biodiversity Heritage Library, the world's largest open access digital library for biodiversity literature and archives. Visit BHL at https://www.biodiversitylibrary.org. 